\title{
Impact of COVID-19 Pandemic School Close Down on the Research Programme of Higher Institutions
}

\author{
Ogunode Niyi Jacob ${ }^{1}$ \\ ${ }^{1}$ Federal University Wukari, Taraba State, Nigeria
}

\begin{tabular}{l}
\hline Article Info \\
\hline Article history: \\
Received Mar 29, 2020 \\
Revised Apr 20, 2020 \\
Accepted Apr 25, 2020 \\
\hline
\end{tabular}

\section{Keywords:}

Covid-19

Research Programme

Higher Institutions

\begin{abstract}
The purpose of this study is to examine the impact of Covid-19 pandemic school close down on the research programme of higher institutions in Abuja, Nigeria. Descriptive survey design was used for the study and 4 research questions was developed for the study. Random sampling method was used to select 120 researchers in the four sampled institutions. The instrument used for collection of data was a structured questionnaire. Result collected revealed that $100 \%$ of the respondents agreed that Covid- 19 pandemic school closure have impact on research program of higher institutions in FCT, $100 \%$ of the respondents agreed that Covid-19 pandemic will affects the flow of international research grants into higher institutions in FCT, $92 \%$ of the respondents agreed that Covid-19 pandemic will affects government funding of research higher institutions in FCT and 100\% agreed that higher institutions as part of their community services by creating awereness to the general public on prevention of Covid-19. The study also showed that $100 \%$ of the respondents agreed that higher institutions in Federal Capital Territory are collaborating with other institutions on the research for Covid-19 vaccine while $69.17 \%$ of the respondents agreed that higher institutions in FCT are producing face masks for free distributions for the people to protect them from containing the Covid-19 in Abuja. Based on this finding, this paper thereby recommends that government should increase the funding of research programme in Abuja and other higher institutions in the country.
\end{abstract}

This is an open access article under the CC BY-SA license.

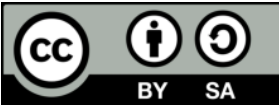

Corresponding Author:

Ogunode Niyi Jacob,

Federal University Wukari, Taraba State, Nigeria

Email: ogunodejacob@gmail.com

\section{INTRODUCTION}

Defines Higher Education as the Post -Secondary Section of the National education system, which is given of Universities, Polytechnics and Colleges of Technology including courses as are given by the Colleges of Education, Advanced Teachers Training colleges, Correspondence Colleges and such institutions as may be allied to them [1]. According to [2], Higher Education refers to a system which embraces much of the country's research capacity and reproduces majority of the skilled professionals that are required in the labour market. Views higher education thus" .. Higher Education is taken to embody all organized learning and training activities at the tertiary level. This includes conventional universities, those with the conventional arts, humanities and science faculties as well as specialized universities like institutions specializing in agriculture, engineering, science, and technology [4]. It also includes post-secondary institutions such as the polytechnics and colleges of education. "Higher Education" includes all forms of professional institutions drawing from the available pool of persons who have completed a various forms of secondary school education: 
Institution of the military, the police, nurses, agriculture, forestry, veterinary workers, catering services, tourism, secretarial services and other possible combinations of programmes. Even this wide spectrum does not exhaust the possibilities of forms of Higher Education...... such as non formal higher education. Indeed, any situations in which mature persons are organized for building up their knowledge and skills, to apply knowledge to the analysis and search for solutions to life problems." The objectives of Higher education in nigeria including the following:

- the acquisition, development and inculcation of the proper value orientation for the survival of the individual and societies;

- the development of the intellectual capacities of individuals to understand and appreciate environment;

- the acquisition of both physical and intellectual skills which will enable individuals to develop into useful members of the community;

- the acquisition of an overview of the local and external environments [1].

The National Policy on Education again stated that higher educational institutions should pursue these goals through: Teaching, Research, the dissemination of existing and new information, the pursuit of service to the community; and by being a store- house knowledge [1].

Observes that from the global perspective, economic and social developments are increasingly driving the advancement and application of knowledge. Education in general and higher education in particular, are fundamental to the construction of a knowledge economy and society in all nations. The nation looks up to higher education to through its traditional functions of teaching, research and community service to develop manpower and disseminate necessary knowledge that are needed in industry and other sectors. The Nigeria higher education system comprised of universities, polytechnics, and colleges offering programmes in teacher education and agriculture. Higher education is a community of scholars, free to pursue knowledge without undue interference from anywhere.

There is need to make research the centre of institutional activity, taking into account the social; cultural; and political problems that Nigeria now faces. Financial and administrative limitations and lack of resources; intellectual stimulation; and incentives demand that we find new strategies to advance this ambition. There is a diminishing scope of mentoring junior researchers by seasoned and senior researchers due to brain drain. Despite the increasing value of research in the world economy based on the supremacy of knowledge; and constant technological change; budgetary constraint; and the belief that research is costly have resulted in the virtual disappearance of research centres in Nigerian higher education.

Universities in Nigeria should make research and development their top priorities. What makes a university unique is the special service it provides for its immediate community. Such specialized services are derived from the results of research it conducts. Universities have made important contributions to the growth and development of nations through research. By producing graduates with new and current ideas, universities make important contributions towards creating innovations for growth and development of industries and government businesses, thereby promoting wealth and development. Roseline [7] said that universities support knowledge driven economic growth strategies and poverty reduction by generating new knowledge, building the capacity to access existing stores of global knowledge and to adapt that knowledge to local use. Technical innovations and their diffusion lead to higher productivity and most innovations are products of basic and applied research undertaken in the universities. Progress in agriculture, health, environmental sectors, science, engineering and technology is heavily dependent on the application of such innovations.

Reports a survey which investigated the funding of library research in six federal government owned universities in Nigeria, and the impact of research funding on the publication output of librarians. Findings indicate that research is either self-funded, or funded by the respondents' employers, and an insignificant number have been funded by international agencies. Grants are given for postgraduate degree and personal research. About half the respondents see the research grants they receive to be either fairly adequate or adequate: but the majority expressed dissatisfaction with

\footnotetext{
Impact of COVID-19 Pandemic School Close Down on the Research Programme... (Ogunode Niyi Jacob)
} 
their research allowances. All agreed that enhanced research grants and allowances would lead to a greater research output. Most publications produced by the respondents resulted from self-funded research, followed by research sponsored by grants from employers, and lastly from researches funded by foundations, agencies and associations.

Did a study and indicated that the University of Benin utilized a total of N71, 592,839 for teaching and research equipment from 1992/93 to 1996/97 academic sessions. This figure is equivalent to $\$ 550,714(\$ 1=\mathrm{N} 130)$. Thus, the average allocation for teaching and research equipment was $\$ 110,143$ per academic session from 1992/93 to 1996/97. This amount is grossly inadequate for teaching and research equipment. The figure is representative of the funding of teaching and research equipment in other universities in Nigeria [7,9]. The findings also agree with [8] as cited by [7] that the federal government makes little investments in research and development, particularly in high priority areas such as agriculture, natural sciences, applied sciences, health sciences, engineering and technology. The inadequate funding has affected the activities in science laboratories, which lack most basic facilities, at the University of Benin [7, 10]. It has led to persistent outcries from the Academic Staff Union of Nigerian Universities (ASUU) for improved funding of universities generally and research specifically. The inadequate funding for research limits the capacity of the universities to fully contribute to Nigeria's development and integrate themselves to the global knowledge networks. The implication of this finding is that universities in Nigeria do not yet possess adequate research capabilities and funding needed to make them active beneficiaries of global knowledge, generate, cull or adapt knowledge, innovations and problem solving.

Observes that the Academic Staff Union of Universities (ASUU) has identified lack of facilities; poor teaching environment and absence of incentives as some of the factors responsible for dearth of research in our institutions [11]. ASUU president, Prof. Biodun Ogunyemi while reacting to claims by the National Universities Commission (NUC) that about N3 billion available under the national research fund at Tertiary Education Trust Fund (TETFund) have not been accessed said academics are less attracted to the grant because the facilities for a sound and effective research are not there.

Nigerian higher institutions have not being doing well in research. Research programme of higher institutions have not being given maximum attention and the programme have not be stable due to many internal crisis. The Federal Ministry of Education in Nigeria has directed all educational institutions in Nigeria to shut down and allow students to go home as cases of reported COVID-19 increased to 13. The Permanent Secretary in the Ministry of Education, Sonny Echono, told reporters on 19 March that the directive was part of the country's overall strategy to contain the spread of the virus. Nigeria joins the growing list of countries in Africa which have closed schools and universities.

The directive include all the higher institutions in Nigeria and in Abuja the capital of Nigeria. Many higher institutions in Abuja since the directive have shut down all academic activities in their various institutions. The Covid-19 pandemic schools close down will definitely affects all the schools programme especially the research programmes. This paper is aim to examines the impact of Covid19 pandemic school close down on research programme of higher institutions in Abuja, Nigeria.

\section{LITERATURE REVIEW}

According to the World Health Organization (WHO), corona viruses are a family of viruses that cause illnesses ranging from the common cold to more severe diseases such as severe acute respiratory syndrome (SARS) and the Middle East respiratory syndrome (MERS).These viruses were originally transmitted from animals to people. SARS, for instance, was transmitted from civet cats to humans while MERS moved to humans from a type of camel. Several known corona viruses are circulating in animals that have not yet infected humans. The name corona virus comes from the Latin word corona, meaning crown or halo. Under an electron microscope, the looks like it is surrounded by a solar corona. The novel corona virus, identified by Chinese authorities on January 7 and since named SARS-CoV-2, is a new strain that had not been previously identified in humans. Little is known about it, although human-to-human transmission has been confirmed [12].

International Journal of Advances in Data and Information Systems, Vol. 1, No. 1, April 2020 : 40 - 49 
Chinese health authorities are still trying to determine the origin of the virus, which they say likely, came from a seafood market in Wuhan, China where wildlife was also traded illegally. On February 7, Chinese researchers said the virus could have spread from an infected animal species to humans through illegally-trafficked pangolins, which are prized in Asia for food and medicine. Scientists have pointed to either bats or snakes as possible sources of the virus.

According to the WHO, signs of infection include fever, cough, and shortness of breath and breathing difficulties. In more severe cases, it can lead to pneumonia, multiple organ failure and even death. Current estimates of the incubation period - the time between infection and the onset of symptoms - range from one to 14 days. Most infected people show symptoms within five to six days. However, infected patients can also be asymptomatic, meaning they do not display any symptoms despite having the virus in their systems [12].

On 27 February, Nigeria confirmed its first case in Lagos State, an Italian citizen who works in Nigeria had returned on 25 February from Milan, Italy through the Murtala Muhammed International Airport, fell ill on 26 February and was transferred to Lagos State Biosecurity Facilities for isolation and testing. Presently, Nigeria is having 199 Covid-19 cases, two death and twenty recovered. In order to contain the spread of the virus in Nigeria, the Federal Ministry of Education has directed all educational institutions in Nigeria to shut down and allow students to go home as cases of reported COVID-19 increased to 13 [13].

From February 27 till May 10, the virus have infected over 434 people, spread to 34 out of 36 states of federation. Over 600 have recovered from the Covid-19 and the fatalities rate is 95 . Submits that eighty-three thousand to 190000 people in Africa could die of COVID-19 and 29 million to 44 million could get infected in the first year of the pandemic if containment measures fail, a new study by the World Health Organization (WHO) Regional Office for Africa finds [14]. The research, which is based on prediction modelling, looks at 47 countries in the WHO African Region with a total population of one billion. The new estimates are based on modifying the risk of transmission and disease severity by variables specific to each country in order to adjust for the unique nature of the region. The model predicts the observed slower rate of transmission, lower age of people with severe disease and lower mortality rates compared to what is seen in the most affected countries in the rest of the world. This is largely driven by social and environmental factors slowing the transmission, and a younger population that has benefitted from the control of communicable diseases such as HIV and tuberculosis to reduce possible vulnerabilities. The lower rate of transmission, however, suggests a more prolonged outbreak over a few years, according to the study which also revealed that smaller African countries alongside Algeria, South Africa and Cameroon were at a high risk if containment measures are not prioritized.

Observes that the outbreak of pandemic Covid-19 all over the world has disturbed the political, social, economic, religious and financial structures of the whole world. World's topmost economies such as the US, China, UK, Germany, France, Italy, Japan and many others are at the verge of collapse [15]. Besides, Stock Markets around the world have been pounded and oil prices have fallen off a cliff. In just a week 3.3 million Americans applied for unemployment and a week later another 6.6 million people started searching for jobs. Also, many experts on economic and financial matters have warned about the worsening condition of global economic and financial structure. Such as Kristalina Georgieva, Managing Director of International Monitory Fund (IMF), explained that "a recession at least as bad as during the Global Financial Crisis or worse". Moreover, Covid-19 is harming the global economy because the world has been experiencing the most difficult economic situation since World War-II. When it comes to the human cost of the Coronavirus pandemic it is immeasurable therefore all countries need to work together with cooperation and coordination to protect the human beings as well as limit the economic damages. For instance, the lockdown has restricted various businesses such as travelling to contain the virus consequently this business is coming to an abrupt halt globally.

Submits that the coronavirus (COVID-19) pandemic that has swept across the globe in the last few weeks and months has not only had a significant impact on public health, society, and the economy as a whole, it has also wreaked havoc to the sporting calendar [16]. In a bid to stem the spread of the virus, many professional and amateur leagues across all continents and sports took the

Impact of COVID-19 Pandemic School Close Down on the Research Programme... (Ogunode Niyi Jacob) 
unprecedented step to postpone or suspend their seasons on the advice of the CDC to avoid gatherings of large amounts of people.

Observes that the COVID-19 pandemic and the measures put in place to contain its diffusion are taking a heavy toll on the tourism sector [17]. According to the United Nations World Tourism Organization (UNWTO), the COVID-19 pandemic will result in a contraction of the tourism sector by $20 \%$ to $30 \%$ in 2020 . Observes that No matter where in the world or in which sector, the crisis is having a dramatic impact on the world's workforce", ILO said in its latest report. "Policy responses need to focus on providing immediate relief to workers and enterprises in order to protect livelihoods and economically viable businesses, particularly in hard-hit sectors and developing countries [18]." An additional concern is the fact that in low and middle-income countries, the worst-hit industries and services have a high proportion of low-wage workers in informal employment, with limited access to health services and State welfare safety nets. "Without appropriate policy measures, workers face a high risk of falling into poverty and will experience greater challenges in regaining their livelihoods during the recovery period", ILO said in its latest report on the situation. It underscored that around two billion people work informally, most of them in emerging and developing countries, and that "tens of millions" of informal workers have already been affected by COVID-19. In urban areas, moreover, these workers also tend to work in economic sectors that "not only carry a high risk of virus infection but are also directly impacted by lockdown measures": waste recyclers, street vendors and food servers, construction workers, transport workers and domestic workers. Highlighting the impacts already being felt in India, ILO pointed out that with its share of almost 90 per cent of people working in the informal economy, about 400 million workers in the vulnerable sector now face falling greater impoverishment. Current lockdown measures there have impacted these workers significantly, forcing many of them to return to rural areas, ILO explained, adding that Brazil and Nigeria had a similar level of informal employment as India, and faced the same risks.

Conducted a study is to find out the perception of undergraduate students on the impact of Covid-19 pandemic on higher education development in Federal Capital Territory, Abuja, Nigeria [19]. This study adopted the descriptive research design of the survey type. The study population comprised all higher institutions in FCT, Nigeria. Out of this population, a sample of two higher institutions was taken and selected through the stratified random sampling technique. Out of the $2,05,878$ undergraduate students, 200 undergraduate students made up of final years students were selected from the sampled two higher institutions. The method of selection was also through the stratified random sampling technique. The instrument used to collect data for the study was a questionnaire titled "Perception of Undergraduate Students on the Impact of COVID-19 Pandemic on Higher Institutions Development Questionnaire. The questionnaire was in two parts A and B. Part A was demographic. The reliability of instrument was determined using the test-retest reliability techniques. The instruments were administered through the use online medium. Data collected were analyzed using simple percentage and Chi-square test was used to test the hypotheses. Result collected and analyzed showed that; $100 \%$ of the respondents agreed that Covid- 19 pandemic affects the academic calendar of higher institutions; $90.5 \%$ of the respondent agreed that Covid-19 pandemic would have effect on implementation of higher institutions financial budget for $2020 ; 94.5 \%$ of the respondents agreed that Covid-19 pandemic have relationship with reduction of manpower in higher institutions; $100 \%$ of the respondents agreed that Covid-19 pandemic have relationship with the cancelation of academic conferences of higher institutions and $89 \%$ of the respondents agreed that online education is the alternative measures for conversional in class teaching and learning for future occurrences of any pandemic.

Did a study to find out the effects of COVID-19 Schools Close Down on the Senior Secondary School Academic Programme [20]. A survey research design was adopted for this study. This research work was carried out in Abaji area council of FCT, Abuja, Nigeria. There are a total number of eight (8) secondary schools in the area of study. Out of the entire teacher population in the area council, (80) teachers were sampled because of the school close down problem. A structured questionnaire, titled the 'Effects of COVID-19 Schools Close Down on the Senior Secondary School Academic Programme Questionnaire' (ECSCDSSAPQ) was used for obtaining information for the

International Journal of Advances in Data and Information Systems, Vol. 1, No. 1, April 2020 : 40 - 49 
study. Simple random techniques were used to select the sample size. The reliability of the instrument was determined through the test re-test method. Data collected were analyzed using simple percentage. Result collected revealed that $80(100 \%)$ of the respondents strongly agreed that COVID19 Schools close down would affect the academic programme of Senior Secondary Schools; 80 $(100 \%)$ of the respondents strongly agreed that COVID-19 schools close down has led to suspension of internal and external examinations reduction in investment on education; $80(100 \%)$ of the respondents strongly agreed that COVID-19 schools close down has led to suspension of teaching and learning in Schools; 80 (100\%) of the respondents strongly agreed that COVID-19 schools close down has affected the academic calendar of senior secondary schools and $80(100 \%)$ of the respondents strongly agreed that COVID-19 schools close down has led to the suspension of all extra-curriculum activities in Senior Secondary Schools. The paper recommends that the Minister of education should direct all Senior Secondary Schools administrators to come up with strategies to cover up the one month teaching and learning gap created as result of the COVID $=19$ schools closed down.

Wrote an article in which they identified the following as the impact of COVID -19 on higher institutions; reduction of international education, disruption of academic calendar of higher institutions, cancellation of local and international conferences, creating teaching and learning gap, loss of man power in the educational institutions, and cut in budget of higher education [21]. The article suggests that the government should take the following measure; increase the funding of higher institutions to enable the institutions manage the damages caused by the COVID-19 pandemic school close down

According to UNESCO, 9.8 million African students are experiencing disruption in their studies due to the closure of higher education institutions [22]. The danger of contamination has triggered institutions to move their courses online. However, going online is not that simple on a continent where only $24 \%$ of the population has access to the internet, and poor connectivity, exorbitant costs and frequent power interruptions are serious challenges.

\subsection{Purpose of the Study}

From the above reviewed literature, it is clear that researchers have not actually look at the impact of Covid-19 pandemic school close down on the research programme of the higher institutions. Based on this research gap, this paper seeks to find out the impact of Covid-19 pandemic schools close down on the research programme of higher institutions in Abuja.

\subsection{Research Questions}

The following research questions were developed for the study. They include

1. Does Covid-19 pandemic school closure have impact on research program of higher institutions in FCT?

2. Would Covid-19 pandemic affects the flow of international research grants into higher institutions in FCT?

3. Would Covid-19 pandemic affects government funding of research higher institutions in FCT?

4. What are the higher institutions doing to contain the spread of Covid-19 in FCT?

\section{METHODS AND MATERIALS}

This study which examined the impact of Covid-19 pandemic school close down on the research programme of higher institutions in Abuja, Nigeria. The study used descriptive survey design. The population of the study constituted all the public higher institutions in Abuja. Out of this, 120 researchers within the four sampled institutions. Random sampling technique was used select the respondents. The reason for the choice of the researchers is that they handles the research programme in the institutions. Four research questions were developed for the study. The instrument for data collection was a 6 item questionnaire adapted by the researchers titled 'Impact of Covid-19 Pandemic School Close Down on the Research Programme of Higher Institutions Questionnaire (ICPSCRPHIQ). The instrument was validated by two researchers. Cronbach Alpha reliability coefficient was adopted to determine the internal consistency of the questionnaires items. The

\footnotetext{
Impact of COVID-19 Pandemic School Close Down on the Research Programme... (Ogunode Niyi Jacob)
} 
reliability coefficient collected was 0.74 which shows that the questionnaire is reliable for the study. The questionnaire was sent to the researchers through their emails. Their email addresses was collected through their various department. The respondent were containted and they accepted to participant in the research as respondents. The return of answered questionnaire was $100 \%$ sent through their email to the researchers. The data collected was analyzed using simple percentage.

In this section, it is explained the results of research and at the same time is given the comprehensive discussion. Results can be presented in figures, graphs, tables and others that make the reader understand easily $[2,5]$. The discussion can be made in several sub-chapters.

\section{DATA ANALYSIS AND DISCUSSION}

Research Question 1: Does Covid-19 pandemic school closure have impact on research program of higher institutions in FCT?

Table 1: Covid-19 papandemic school closure have impact on research program of higher institutions in FCT

\begin{tabular}{|c|c|c|}
\hline Responses & Frequency & Percentage (\%) \\
\hline Strongly Agree & 78 & 61 \\
\hline Agree & 42 & 39 \\
\hline Disagree & 0 & 0 \\
\hline Strongly Disagree & 0 & 0 \\
\hline Total & $\mathbf{1 2 0}$ & $\mathbf{1 0 0}$ \\
\hline
\end{tabular}

To find out if Covid-19 pandemic school closure have impact on research program of higher institutions in FCT. Result collected from research question one revealed that $61 \%$ of the respondents strongly agree that Covid-19 pandemic school closure has impact on research program of higher institutions in FCT while 31\% agreed that Covid-19 pandemic school closure has impact on research program of higher institutions in FCT. This means that $100 \%$ of the respondents agreed that Covid19 pandemic school closure have impact on research program of higher institutions in FCT.

Research Question 2: Would Covid-19 pandemic affects the flow of international research grants into higher institutions in FCT?

Table 2: Covid-19 pandemic will affects the flow of international research grants into higher institutions in FCT

\begin{tabular}{|c|c|c|}
\hline Responses & Frequency & Percentage (\%) \\
\hline Strongly Agree & 78 & 61 \\
\hline Agree & 42 & 39 \\
\hline Disagree & 0 & 0 \\
\hline Strongly Disagree & 0 & 0 \\
\hline Total & $\mathbf{1 2 0}$ & $\mathbf{1 0 0}$ \\
\hline
\end{tabular}

To find out if Covid-19 pandemic will affects the flow of international research grants into higher institutions in FCT. Result collected from research question one revealed that $61 \%$ of the respondents strongly agree that Covid-19 pandemic will affects the flow of international research grants into higher institutions in FCT while 31\% agreed that Covid-19 pandemic will affects the flow of international research grants into higher institutions in FCT. This means that $100 \%$ of the respondents agreed that Covid-19 pandemic will affects the flow of international research grants into higher institutions in FCT.

Research Question 3: Would Covid-19 pandemic affects government funding of research higher institutions in FCT?

Table 3: Covid-19 pandemic will affects government funding of research higher institutions in FCT

\begin{tabular}{|c|c|c|}
\hline Responses & Frequency & Percentage (\%) \\
\hline Strongly Agree & 73 & 68.8 \\
\hline Agree & 22 & 18.33 \\
\hline Disagree & 10 & 8.88 \\
\hline Strongly Disagree & 5 & 4.16 \\
\hline Total & $\mathbf{1 2 0}$ & $\mathbf{1 0 0}$ \\
\hline
\end{tabular}


To find out if Covid-19 pandemic affects government funding of research higher institutions in FCT. Research from research question three revealed that $60.8 \%$ ticked strongly agreed, $18.33 \%$ ticked agreed while $8.33 \%$ ticked disagreed and $4.16 \%$ ticked strongly disagreed that Covid- 19 pandemic will affects government funding of research higher institutions in FCT. The result showed that majorities of the respondents agreed that Covid-19 pandemic will affects government funding of research higher institutions in FCT.

19 in FCT?

Research Question 4: What are the higher institutions doing to contain the spread of Covid-

Table 4: What are the higher institutions doing to contain the spread of Covid-19 in FCT

\begin{tabular}{|c|l|c|c|c|c|c|}
\hline $\mathrm{S} / \mathrm{N}$ & $\begin{array}{l}\text { Higher institutions are doing the following to } \\
\text { contain the spread of Covid-19 in FCT }\end{array}$ & SA & SD & $\%$ & TOTAL \\
\hline 1 & $\begin{array}{l}\text { Public awereness to contain the spread of } \\
\text { Covid-19 }\end{array}$ & 120 & 100 & - & - & 120 \\
\hline 2 & $\begin{array}{l}\text { Collaborating with other institutions on the } \\
\text { research for Covid-19 vaccine }\end{array}$ & 120 & 100 & - & - & 120 \\
\hline 3 & Manufacturing of facemask & 83 & 69.17 & 37 & 30.83 & 120 \\
\hline
\end{tabular}

The research also want to know what the higher institutions are doing to contain the spread of Covid-19 in FCT. The result collected showed that in research three item one, $100 \%$ of the respondents agreed that higher institutions as part of their community services are create awereness to the general public on prevention of Covid-19. The item two of question three revealed that $100 \%$ of the respondents agreed that higher institutions in Federal capital territory are collaborating with other institutions on the research for Covid-19 vaccine while the item three on research question three showed that $69.16 \%$ of the respondents agreed that higher institutions in FCT are producing face masks for free distributions for the people to protect them from containing the Covid-19 in Abuja while 30.83

\section{DISCUSSION OF RESULT}

To find out if Covid-19 pandemic school closure have impact on research program of higher institutions in FCT. Result on table 1 showed that $100 \%$ of the respondents agreed that Covid-19 pandemic school closure have impact on research program of higher institutions in FCT. To find out if Covid-19 pandemic will affects the flow of international research grants into higher institutions in FCT.

Table 2 revealed that $100 \%$ of the respondents agreed that Covid-19 pandemic will affects the flow of international research grants into higher institutions in FCT. This result is contrary to the submission of [23] who observes that despite the COVID-19 crisis, the European Union (EU) contribution to Africa is not likely to be affected. Even though every state's first response to the pandemic has been to close its borders, "we are completely interdependent - even if a country manages to defeat the virus, it will never be safe until it is defeated everywhere," he said. Palmowski said the EU has directed $€ 3.25$ billion (US $\$ 3.5$ billion) towards the coronavirus response in Africa. "This is not new money, because EU budgets are set a long time in advance and the EU has limited means to change budgets within budget periods. But it is accelerating funding, also in the hope of attracting further private investment." It said it will secure financial support to partner countries amounting to more than $€ 15.6$ billion from existing external action resources. "Together with our partners, we are making sure that the substantial EU funding already allocated to them is targeted to help them deal with the impact of the coronavirus pandemic," it said in a press

To find out if Covid-19 pandemic affects government funding of research higher institutions in FCT. Table three disclosed that $60.8 \%$ ticked strongly agreed, $18.33 \%$ ticked agreed while $8.33 \%$ ticked disagreed and $4.16 \%$ ticked strongly disagreed that Covid-19 pandemic will affects government funding of research higher institutions in FCT. The result showed that majorities of the respondents agreed that Covid-19 pandemic will affects government funding of research higher institutions in FCT. This result is in agreement with [9], who submits that the total amount expended on research annually by the federal government is approximately on average $0.02 \%$ of the Gross Domestic Product (GDP). Opines that the inadequate funding for research limits the capacity of the 
universities to fully contribute to Nigeria's development and integrate themselves to the global knowledge networks [7]. The implication of this finding is that universities in Nigeria do not yet possess adequate research capabilities and funding needed to make them active beneficiaries of global knowledge, generate, cull or adapt knowledge, innovations and problem solving.

To find out if what higher institutions are doing to contain the spread of Covid-19. The result collected on this area showed that in research three item one, $100 \%$ of the respondents agreed that higher institutions as part of their community services are enlightening the general public on prevention of Covid-19. The item two of question three revealed that $100 \%$ of the respondents agreed that higher institutions in Federal Capital Territory are collaborating with other institutions on the research for Covid-19 vaccine while the item three on research question three showed that $69.16 \%$ of the respondents agreed that higher institutions in FCT are producing face masks for free distributions for the people to protect them from containing the Covid-19 in Abuja while 30.83ticked disagreed.

\section{CONCLUSION}

The purpose of this paper is to find out the impact of Covid-19 on the research programme of higher institutions in Abuja, Nigeria. Specific objectives includes:

- To find out if Covid-19 has impact on the research programme of higher institutions in Abuja, FCT.

- To find out if Covid-19 will affect the flow of international research grant into higher institutions in Abuja and to find out what the higher institutions are doing to contain the spread of Covid-19 in Abuja.

From the result collected from the study, it can be established that Covid-19 pandemic school closure have impact on research program of higher institutions in FCT and that Covid-19 pandemic will affects the flow of international research grants into higher institutions in FCT. The result also showed that Covid-19 pandemic will affects government funding of research higher institutions in FCT and that higher institutions as part of their community services are creating awereness to the general public on prevention of Covid-19. It was gathered that higher institutions in Federal Capital Territory are collaborating with other institutions on the research for Covid-19 vaccine while higher institutions in FCT are producing face masks for free distributions for the people to protect them from containing the Covid-19 in Abuja.

Based on this finding, the paper hereby recommends that:

- The government should increase the funding of research programme in Abuja and other higher institutions in the country.

- The international communities and international organizations should support and increase their research grant in Nigeria higher institutions

- The administrators of higher institutions should encourage their academic staff to carry out researches constantly

- Higher institutions across the globe should come together and collaborate to research on vaccine for Covid-19.

\section{REFERENCES}

[1] Federal Republic of Nigeria (2004) National Policy on Education, Lagos: FRN.

[2] Adeyemi, K. (2001). Equality of Access and Catchment Area; Factor in, University Admission in Nigeria, Journal of Higher Education 42:307 -322

[3] Obanya, P. (1999), Higher Education for an Emergent Nigeria: Faculty of Education,

[4] University of Ibadan 5th Anniversary Lecture, Ibadan. Heinemann Education Books (Nigeria Plc), Noun (42009)

[5] Okebukola, P. (2004). Strategies for stimulating research and development in Nigerian universities. Nigerian University Chronicle, 12(2), 17-18.

[6] Innocent, I, E. (1999). The funding of library research in Nigerian universities, Journals Library Management Volume 20 Issue 6 
[7] Roseline, O, O.(2012) Federal Government Funding of Research in Universities in Nigeria, the University of Benin as a Case Study. International Education Studies; Vol. 5, No. 6; ISSN 1913-9020 E-ISSN $1913-$ 9039 Published by Canadian Center of Science and Educatio

[8] Oyewole, B. O. (2006). A Model Research Coordinating Effort in an African University. Paper presented at the Second International Colloquium on Research and Higher Education Policy. UNESCO Headquarters, Paris, France. 29th November - 1st December.

[9] Fadokun, J. B. (2000). University Research Capacity in Nigeria and the challenges of National Development in a Knowledge based economy. Journal of Social Scientist, 5(1), 1-23.

[10] Osagie, R. O. (2012). Financial Allocation and its Utilization in the Science Laboratories, University of Benin, Edo State, Nigeria. European Journal of Educational Studies, 4(2), 291-299

[11] Nigeria: Why Academics Are Not Accessing Research Grants - ASUU President https://allafrica.com/stories/201802160227.html

[12] Ajazeera (2020). Corona virus: All you need to know about symptoms and risks.https://www.aljazeera.com/news/2020/01/coronavirus-symptoms-vaccines-risks200122194509687.html

[13] Wikipedia. (2020). Impact of the 2019-20 coronavirus pandemic on education. https://en.wikipedia.org/wiki/Impact_of_the_2019\%E2\%80\%9320_coronavirus_pandemic_on_educatio $\mathrm{n}$

[14] New WHO estimates: Up to 190000 people could die of COVID-19 in Africa if not controlled remarks: https://www.afro.who.int/regional-director/speeches-messages/opening-statement-Covid-19press-conference-7-may-2020

[15] Irfan, M. (2020) Impact of Covid-19 on Global Economy Structure. https://moderndiplomacy.eu/2020/04/22/impact-of-Covid-19-on-global-economy-structure/

[16] Christina, G. (2020) Coronavirus (COVID-19) disease pandemic effect on the sports industry - Statistics \& Facts. https://www.statista.com/topics/6098/impact-of-the-coronavirus-on-sport/

[17] Pamela, C. (2020) Impact of COVID-19 on tourism in small island developing states. https://unctad.org/en/pages/newsdetails.aspx?OriginalVersionID $=2341$

[18] COVID-19: impact could cause equivalent of 195 million job losses, says ILO chief. https://news.un.org/en/story/2020/04/1061322

[19] Deborah, J. (2020) Perception of Undergraduate Students on the Impact of COVID-19 Pandemic on Higher Institutions Development in Federal Capital Territory Abuja, Nigeria, Electronic Research Journal of Social Sciences and Humanities Vol 2: Issue II ISSN: 2706 - 8242 www.eresearchjournal.com Apr - Jun 2020

[20] Ogunode, N, J.(2020) Effects of COVID-19 Schools Close Down on Academic Programme of Senior Secondary Schools in Abaji Area Council of Federal Capital Territory Abuja, Nigeria. Electronic Research Journal of Social Sciences and Humanities Vol 2: Issue II ISSN: 2706 - 8242 www.eresearchjournal.com Apr - Jun 2020

[21] Ogunode, N, J. Abigeal, I. \& Lydia, A. E. (2020) Impact of COVID-19 on the Higher Institutions Development in Nigeria. Electronic Research Journal of Social Sciences and Humanities Vol 2: Issue II ISSN: 2706 - 8242 www.eresearchjournal.com Apr - Jun 2020

[22] UNESCO.(2020).COVID-19 Education Response https://en.unesco.org/covid19/educationresponse

[23] Francis, K. (2020) Investment in public research universities set to continue.https://www.universityworldnews.com/post.php?story=20200427121209316 